\title{
Mankind's Existence as First Commandment in Hans Jonas: Lessons for Contemporary Humanity
}

\author{
Dr. Peter Takov \\ Catholic University of Cameroon, Bamenda, Cameroon
}

\begin{abstract}
This paper seeks to present Hans Jonas's view of the primacy of human existence amidst the catastrophes wrought by modern technology. It suggests that we understand the existence of mankind as the first commandment. Mankind today, more than ever before, stands as the main instrument of technological manipulation as evinced by recent scientific endeavours: genetic manipulation, human cloning as well as extension of human lifespan, not excluding the threat of a nuclear war. Although mankind has never been without technology, the negative consequences of modern technology are a call for concern. In line with Jonas's novel ethic, we anchor the starting point of mankind's responsibility for the care of the present and future generations on metaphysics. This is in a bid to bridge the yawning gap between the scientifically ascertained "is" and the morally binding "ought"in order to save mankind from an impending catastrophe.
\end{abstract}

Key Words: Jonas - Mankind - Existence -Ethics - Metaphysics - Responsibility - Technology

\section{INTRODUCTION}

$\mathrm{D}$ uring the so-called Jazz Age of the Twenties, Walter Lippmann observed that "the acids of modernity" had dissolved the religious certainties of the past. The influences of the scientific method and the growth of industrial and urban societies were largely responsible, he believed, for the loss of faith in absolutes. Even in the realm of morals, he added, the codes we had inherited from the Hebrews of the Old Testament were beginning to dissolve in the spirit of a new age. ${ }^{1}$ These exciting words capture the status quo of an epoch which has been described as an age of science and technology, characterized by its alternating benefits and catastrophic consequences which cannot elude our grasp.

It is within this ambient that Hans Jonas emerges and decries the near deification of human innovative powers in technology which is almost leading mankind to doom as evidenced by nuclear war, ecological ravage and genetic engineering which have today led to a degradation of human dignity as man is now looked upon more as an object of manipulation and research rather than a subject and an end-inhimself. Faced with these calamities, we find ourselves at the crossroads, indecisive on what direction to take; and we cannot help questioning: For what reasons is a being as fragile, contingent and mortal as ours, an absolute value? What incriminates modern technology, given that "man has

${ }^{1}$ L. BINKLEY, "The Age of Relativism,"in A. K. BIERMAN - J. A. GOULD, Philosophy for a New Generation, Macmillan Publishing Co., New York $1970^{4}, 20$ never been without technology"? ${ }^{2}$ How can the existence of mankind be preserved in an era of crisis? Is technology the paradigm of truth?

Very lucidly, Jonas attests to the fact that human beings are today the objects of technological manipulation and research. Unequivocally, he states that the existence of mankind is the first commandment. ${ }^{3}$ Given the above mishaps, engineered by modern technology, Jonas sets out to rethink the foundations of ethics and insists that we realise the fact that the future of mankind is our responsibility, an imperative which lies within metaphysics as a doctrine of being of which man is a part. ${ }^{4}$ In this regard, he propounds an ethics of responsibility in view of safeguarding the future of mankind. In the context of the extant threats to human existence wrought by technology, we unhesitatingly question: What is the meaning of human existence? To what extent is humanity, via technology, permitted to intervene in human life? What makes human existence the "highest given" to be uncompromisingly nurtured and upheld?

To address these questions, the article is divided into three parts. Part one considers the primacy of human existence in Jonas's thought with a focus on man as the object of technology. Part two is an evaluation of Jonas's consideration of modern technology vis-à-vis human existence. Part three focuses on the relevance of the Jonasian "human existence imperative" to our contemporary society and our proposals for a better approach to technology.

\section{Hans Jonas's Ontological Basis of the Imperative of Human Existence in a Technological Age: Redefining the Human Status}

"The existence of mankind comes first, whether deserved on its past record and its likely continuation or not. It is the evertranscendent possibility obligatory in itself, which must be kept open by the continued existence." ${ }^{.5}$ These words, which emphasize the imperative of human existence, constitute the bedrock of H. Jonas' consideration of the exigency of a novel ethics for a technological era. However, in order to pre-empt any accusation of beginning a book from the second chapter,

\footnotetext{
${ }^{2}$ H. JONAS, The Imperative of Responsibility: In Search of an Ethics for the Technological Age, H. JONAS - D. HERR (trans.), The University of Chicago Press, Chicago 1984,1.

${ }^{3} \mathrm{H}$. JONAS, The Imperative of Responsibility, 99.

${ }^{4} \mathrm{H}$. JONAS, The Imperative of Responsibility, 44.

${ }^{5} \mathrm{H}$. JONAS, The Imperative of Responsibility, 99.
} 
it would be suitable for us to examine some influences to Jonas's thought as well as the status quo of the human condition and why it is problematic, hence our imperative of human existence. In verba alia, what led H. Jonas to make this declaration?

One of the main influences to the emergence of Jonas's thought was the existentialism ${ }^{6}$ of Heidegger. In an age when the majority of German-speaking Jewish philosophers were still committed to German Idealism, ${ }^{7}$ there arose the Vienna Circle $^{8}$ which sought to destroy the claim of these idealist philosophers to have ideal access to knowledge and truth. The Logical Positivists rejected idealism and all forms of transcendental metaphysics ${ }^{9}$ as incapable of verification ${ }^{10}$ and as devoid of significance. ${ }^{11}$ Thus, the logical positivists claimed that metaphysical statements to which they included theology and ethics are meaningless on basically two counts: that they do not purport to be analytic and that they cannot be verified or falsified by sensory experience. ${ }^{12}$

Of paramount importance, and an almost immediate trigger which marked a turning point in Jonas's outlook on life, were the Auschwitz murders and the great Holocaust in Germany. ${ }^{13}$ During the Holocaust, Germany's Nazi leader, Adolf Hitler, ordered the extermination of 5.6 to 5.9 million Jews, reason

\footnotetext{
${ }^{6}$ Jonas holds that the root of Heidegger's existentialism, which is nihilistic is his uncritical acceptance of the spiritual denudation of the concept of nature and makes the ontological assumption that there exists a stark divide between human beings and the rest of nature, which inherent dualism diminishes being by denying that living nature is a good-in-itself to which we belong and commands our responsibility. ( H. JONAS, The Phenomenon of Life: Toward a Philosophical Biology, Harper and Row, New York 2001,xiii, xviii).

${ }^{7}$ As opposed to materialism which upholds the reality of matter, idealism refers to the doctrine which emphasizes mind, spirit or soul as the ultimate constitutive element or reality. ( J. I. OMOREgBe,A Simplified History of Western Philosophy, vol. 2, Joja Educational Research and Publishers Ltd., Lagos 1991, 122).

${ }^{8}$ A. J. AYER, Logical Positivism, The Free Pass Press, New York 1959, 3.

${ }^{9}$ The rift which we can term between metaphysics and epistemology took roots in the $18^{\text {th }}$ century with the Enlightenment. During this period, there was a reversal of things: reality (metaphysics) which was formerly the determining factor of thought (epistemology) was rather now subservient to reason, reason why the enlightenment had as motto: "Aude Sapere" - Dare to Think. Consequently, human reason determined everything; free, "unprejudiced"-thinking was the norm, an attempt to bring philosophy out of the closet. [Cfr. F. E. MANuEL (ed.), The Enlightenment, Prentice-Hall Inc., New Jersey 1955,2$]$. As opposed to the medieval period of philosophy during which theocentricism (God-centred reasoning which extended to the realm of human action) was in vogue, anthropocentricism (man in general and human reason in particular) was now rife.

${ }^{10}$ W. D. HUDSON, Ludwig Wittgenstein. The Bearing of his Philosophy upon Religious Belief, John Knox Press, Virginia 1968, 19.

${ }^{11}$ M. J. WALSH, A History of Philosophy, Cassell Ltd, London 1958, 476.

${ }^{12} \mathrm{M}$. J. WALSH, A History of Philosophy, 476.

${ }^{13}$ The great Holocaust refers to the almost complete destruction of Jews in Europe by Nazi Germany and its collaborators during World War II (19391945). Auschwitz was the site of the largest Nazi concentration camp. However, the word holocaust derives from the Greek holo(whole) and caustos(burned) and originally referred to a burnt offering or a religious sacrifice that is totally consumed by fire. [R. BANKIER, "Holocaust," in Microsoft ® Encarta ${ }^{\circledR} 2009$ (DVD), Redmond, WA: Microsoft Corporation,
} 2008]. why the Jews often refer to the Holocaust as Shoah (from the Hebrew word for "catastrophe" or "total destruction"). ${ }^{14}$

Witnessing the highest-ever genocide in history, ${ }^{15}$ which saw not only the murder of Jews, but also of those who opposed the Nazi regime on grounds of ideology, including Germans who were either mentally impaired or physically disabled, homosexuals as well as captured Soviet soldiers, ${ }^{16}$ Jonas could not remain indifferent. The sophisticated armament used during World War II, the murder at killing centres, in concentration camps, the new gassing techniques designed for this purpose in Auschwitz, left an indelible mark on him especially given that his mother was a victim.

With this new outlook, Jonas realized that a variety of ethical problems today are not unconnected with modern technological advancement; Thus, the necessity of making a distinction between technology of antiquity and technology of modernity. ${ }^{17}$

In Jonas's consideration, previous technology concerned itself with an essentially superficial and powerless endeavour in making human life better and in this way, made an insignificant move in upsetting the natural balance. ${ }^{18}$ According to him, pre-modern technology was of no catastrophic consequences to man and nature and he further holds that the present state of affairs is as a result of man's unfettered action in exploiting his inherent wondrous power of innovation and restless cleverness. ${ }^{19}$ Thus, the basic distinctive feature is made manifest by the catastrophic consequences wrought by modern technology: ecological ravage, nuclear wars and genetic manipulation, to name a few. ${ }^{20}$ In this same line of thought, H. Gadamer notes:

Today, modern science viewed in technology is a global reality. It certainly began in Europe, but today its influence on the ways of life in cultural regions other than the European cannot be neglected. In the modern world, since cultures much older than the European one have begun to live with the results and consequences of modern science, the Greek heritage that was succeeded by Europe and its scientific culture finds itself faced with entirely new confrontations. ${ }^{21}$

It is evident that modern science and technology pose new problems and challenges today which impinge on mankind's ultimate dignity and value hence against Jonas's first

\footnotetext{
${ }^{14}$ Ibid.

${ }^{15}$ Ibid.

${ }^{16} \mathrm{Ibid}$.

${ }^{17}$ Technology of antiquity here is synonymous to pre-modern technology and technology of modernity to modern technology. With this distinction, we shall, in this work base ourselves largely on modern technology. Thus if not specified, technology when used would refer to modern technology.

${ }^{18} \mathrm{H}$. JONAS, The Imperative of Responsibility, 3.

${ }^{19}$ Ibid., 4, 6.

${ }^{20}$ Ibid., 8, 19-21.

${ }^{21} \mathrm{H}$ - G. GADAMER, The Beginning of Knowledge, R. COLTMAN (trans.), Continuum, London 2001, 127-128.
} 
commandment. It is against this backdrop that he considers a diverse range of technologically-engineered accomplishments that have a boomerang effect on its initiator.

Mankind's first commandment, Jonas holds, is today, more than ever before under grievous threats as a result of the precipitous technological development of our age. ${ }^{22} \mathrm{He}$ notes that in the past, technology was primordially concerned with the non-human realm (whose effects are today no less alarming). However, he observes that man himself has been added to the objects of technology, getting ready to "make over the maker of all the rest." 23

Amidst the rising tides of technology, Jonas lamentably remarks that man is no longer seen as an end in himself but as a tool for laboratory manipulation under the guise of research, an overt deification of the powers of man. In this light, Jonas considers some bioengineered ventures on man.

One of the plagues of technology handled by Jonas is its venture into the most basic given of man: mortality. $\mathrm{He}$ acknowledges that in the past thesubject of death was looked upon in lament, submission or vain wish dreams about possible exceptions, having in the hind that this condition is unalterable for which reason the earnest man would pray: "teach us to number our days that we may get a heart of wisdom." ${ }^{24}$ However, Jonas notes that "lately the dark cloud of inevitability seems to lift." ${ }^{25}$ Due to advancements in cell biology, attempts are being made to prolong or indefinitely extend the span of life and ageing is seen as a problem or rather a curse; death is no longer seen as a necessity inherent in the nature of life but as an organic malfunction, hence avoidable. This same trend of thought is maintained by the French existentialist J. P. Sartre for whom death is meaningless, an absurdity which robs human life of all meaning. ${ }^{26}$ But then, we are left with the inescapable questions: Who are those eligible for this process of scientific extension of human lifespan? Those who can afford? What about the poor? Then we shall, as a consequence, have a predominantly old population than a young one. Jonas thus holds that what seems a philanthropic gift of science is a curse rather than a blessing. ${ }^{27}$

Another technological adventure which exceeds the categories of previous ethics concerns altering human behaviour for a desired end: the relief of a patient, "correction" of unruly behaviour such as aggression, adjustment of temperament such as inducing sensations of happiness, pleasure or

\footnotetext{
${ }^{22} \mathrm{H}$. JONAS, The Imperative of Responsibility, 17-21.

${ }^{23} \mathrm{H}$. JONAS, The Imperative of Responsibility, 18.

${ }^{24}$ Psalm 90 as quoted in Ibid.

${ }^{25}$ Ibid.

${ }^{26}$ J. P. SARTRE, Being and Nothingness, Methuen, London 1969, 533.

${ }^{27} \mathrm{H}$. JONAS, The Imperative of Responsibility 18-19.
}

contentment. ${ }^{28}$ The methods employed in this process include psychosurgery, ${ }^{29}$ electroshock and electro-stimulation.

Jonas rightly points out that this is a non-human way of dealing with human problems. He further insists that, in addition to the side-effects associated with these impersonal mechanistic methods of altering human behaviour, they take away the personal selfhood of the individual and we are shifted from responsible subjects to programmed behaviour systems even if consented to. ${ }^{30}$

Furthermore, Jonas considers the genetic control of future men in which man seeks to take his evolution in hand by attempting to preserve the integrity of the species and modifying it with his own design. ${ }^{31}$ Via genetic engineering, ${ }^{32}$ man has sought to take the future into his hands but we wonder if he is apt for such a creative role and more importantly, what standards he uses as a canon for "fashioning a human being" by altering his traits.

These are some of the technologically-engineered processes handled by Jonas which have largely altered the human condition and pose a challenge to traditional ethics thus the exigency of a novel ethics. In this light, he advances a wager on human action as a preamble to the ethics of responsibility.

In acting, Jonas contends, man must not undertake any action which would dehumanize humanity. He thus formulates an ethical axiom: "Never must the existence or the essence of man as a whole be made a stake in the hazards of action. ${ }^{\circ 3}$ In this light, he states that the principle of responsibility is the starting point of ethics. ${ }^{34}$ But what is the rationale behind this giant step initiated by Jonas?

The nature of human action, according to Jonas, has changed significantly and traditional ethics ${ }^{35}$ is no longer equipped to handle some of the issues and since ethics deals with action, the rethinking of a new ethics is incumbent. ${ }^{36} \mathrm{But}$ what is the limiting factor of traditional ethics which makes it today illequipped in handling the problem presented by the new age of technology?Jonas gives a fitting response to this when he notes that traditional ethics was designed within and for a given epoch. Thus it took into consideration only the present

\footnotetext{
${ }^{28}$ Ibid., 20.

${ }^{29}$ It is sometimes called "psychiatric neurosurgery." Developed in the 1930 s by the Portuguese neurologist E. Moniz, it is the treatment of psychiatric illness by surgery on the brain. (W. T. REICH (ed.), EncyclopaediaofBioethics Vols. $3 \& 4,1378)$. It is a surgical destruction of some certain parts of the brain for the purpose of treating psychiatric conditions. (B. M. ASHLY - K. D. O'Rourke, HealthCareEthics, The Catholic Hospital Association, New York 1978, 351-352).

${ }^{30} \mathrm{H}$. JONAS, The Imperative of Responsibility, 20.

${ }^{31} \mathrm{H}$. JONAS, The Imperative of Responsibility, 21.

${ }^{32} \mathrm{~W}$. Thomson, A Dictionary of Medical Ethics and Practise, John Wright \& Sons Ltd., Bristol 1977, 132).

${ }^{33} \mathrm{H}$. JONAS, The Imperative of Responsibility, 37.

${ }^{34}$ Ibid., 38.

${ }^{35}$ What H. Jonas calls "neighbour" ethics of justice, charity and honesty, relevant to the day-to-day interaction among men. (Ibid.,6).

${ }^{36}$ Ibid., 23.
} 
or at most the immediate future. ${ }^{37}$ In this regard then, Jonas maintains:

\begin{abstract}
All dealing with the nonhuman world, that is, the whole realm of techne ${ }^{38}$ (with the exception of medicine), was ethically neutral - in respect both of the object and the subject of such action... action on nonhuman things did not constitute a sphere of authentic ethical significance... The good and evil about which action had to care lay close to act, either in the praxis itself or in its immediate reach, and were not matters for remote planning. This proximity of ends pertained to time as well as space... Ethics accordingly was of the here and now... ${ }^{39}$
\end{abstract}

In his view then, previous ethics was characterized by anthropocentricity, an ethics binding at short-range (of the here and now). It is within this trajectory that he proposes an ethics that should cater for human action of both the present and the future.

\section{The Existence Of Mankind As Imperative}

The whole enterprise of Jonas comprises in stressing the fact of the primacy of human existence and itsimperative. In his own words, "the imperative that there be a mankind is the first one, as far as man alone is concerned. ${ }^{, 0} \mathrm{He}$ transforms the Kantian categorical imperative: "Act so that you can will that the maxim of your action be made the principle of a universal law," ${ }^{41}$ to conform to the primacy of human existence: "Act so that the effects of your action are compatible with the permanence of genuine human life." ${ }^{42}$

Jonas also considers the implicit role of nature in the endeavour to keep mankind's first commandment. He notes that unless we think of nature as being a source of value and not a mere resource upon which we project our interests, we will not be able to believe in the importance of limits to our technological remaking of nature. Such limits, he adds, are especially urgent given our increasing power to destroy our habitat and to alter the human image by exerting control over behaviour, the process of dying as well as the genetic make-up of life. ${ }^{43}$ Jonas simultaneously proposes a careful treatment of nature and the ills that threaten human existence, and by implication spells out the priority of our duty to human existence.

\footnotetext{
${ }^{37} \mathrm{H}$. JONAS, The Imperative of Responsibility, 4.

${ }^{38}$ Technerefers to the set of principles involved in the production of an object. It resembles episteme in implying knowledge of principles but differs in that its aim is making or doing not disinterested understanding. (D. D. RUNES (ed.), The Dictionary of Philosophy, Vision Press, London 1964, 314). In H. Jonas's use, it is applied mainly to the nonhuman realm. ( H. JonAs, The Imperative of Responsibility, 18).

${ }^{39}$ Ibid.,4-5.

${ }^{40}$ Ibid., 43.

${ }^{41}$ I. Kant, Critique of Pure Reason, F. M. Muller (trans.), Ancho Books Garden City, New York 1966, 132.

${ }^{42} \mathrm{H}$. JONAS,The Imperative of Responsibility, 11.

${ }^{43}$ L. Vogel (ed.), "Introduction," in H. JonAs, Mortality and Morality: A Search for the Good after the Auschwitz, Northwestern University Press, Illinois 1996, 3.
}

The duty to ensure human existence, Jonas intimates, is the utmost of our duties. In postulating this, he also considers the right of man to procreation as ensuing from a duty to foster human existence. ${ }^{44}$ Leibniz had earlier on affirmed the presence of being and not its opposite by posing the famed question: Why is there something at all rather than nothing? Jonas confirms and justifies this claim by rooting the preference of being in its ontological goodness as willed by God: "that he willed it because its existence is good, not that it is good because he willed it." ${ }^{45}$ In effect, the crux of Jonas' thesis is that the divine creator willed the existence of man because he found that it ought to be. ${ }^{46}$

In recovering the meaning of being, Jonas proceeds in three stages: existential, ontological and theological. From an existential point of view, he argues that purposive existence is not a special attribute of human beings but is present throughout living nature. ${ }^{47}$ Secondly, he provides an ontological grounding of our ethical obligations to nature and ourselves as special products of its evolutionary labours. ${ }^{48}$ Lastly, Jonas' imperative of responsibility - never to let the existence of humanity be threatened by the hazards of action - follows from Judaism's appreciation of the goodness of life and the special dignity of humanity. ${ }^{49}$

Being, Jonas contends, ought ${ }^{50}$ to be; an imperative based on the fact that it is ontologically good, ${ }^{51}$ a stance perfectly in accord with the transcendental property of being as good. ${ }^{52}$ From this point of view, he holds that the categorical import generated by this ontological goodness is the existence of man. Thus he states that our first duty is ontological. ${ }^{53}$

Outstandingly, Jonas posits that through life, being says "yes" to itself. He substantiates this by the fact that all organisms have concern for their own being. Nonetheless, only humans, are able to discern the ontological truth that the presence of life in being is absolutely and infinitely better than its absence. ${ }^{54}$ Hence, humanity as a whole cannot not be.$^{55}$ Thus any action of man which threatens mankind's existence is playing foul with the game of life. ${ }^{56}$

In common usage, value is no longer limited to its strictly economic connotation. Recently, it has become

\footnotetext{
${ }^{44} \mathrm{H}$. JONAS, The Imperative of Responsibility, 41.

${ }^{45}$ Ibid. 47 .

${ }^{46}$ Ibid., 48

${ }^{47}$ L. VOGEL, "Introduction," in H. Jonas, The Phenomenon of Life, xiv.

${ }^{48}$ Ibid.

${ }^{49}$ L. VoGel, "Introduction," in H. Jonas, The Phenomenon of Life, xviii.

${ }^{50}$ The "ought" refers to value statements and the "is" to factual statements. [P. TAKOv, Deriving "Ought" from "Is" According to Hans Jonas, A Doctoral Thesis in the Faculty of Philosophy at the Pontifical Urban University, (Unpublished), Rome 2009, 53].

${ }^{51} \mathrm{H}$. JONAS, The Imperative of Responsibility, 47.

${ }^{52}$ The other transcendental properties pertaining to being are: One (unит), True (verum) and Beautiful (pulchrum). (T. AlviRAetalii,Metaphysics, L. SuPAN (trans.), Sinag-Tala Publishers, Manila 1991, 129).

${ }^{53} \mathrm{H}$. JONAS, The Imperative of Responsibility, 43.

${ }^{54} \mathrm{H}$. Jonas, The Phenomenon of Life: Toward a Philosophical Biology, xvi.

${ }^{55}$ IDEM,The Imperative of Responsibility, 130.

${ }^{56}$ Fair play would be keeping the first commandment.
} 
interchangeable with the good, reason why friendship, for instance, is at times called a good and at other times a value. ${ }^{57}$ Tallying with this, Jonas maintains that "value" is easily tied to the questions: "For whom?" and "How much?" commensurate to appraisal and exchange. ${ }^{58}$

Departing from this capitalistic and misconstrued view of the value as interchangeable with the good, Jonas notes, in accord with sound metaphysics, that the good, as compared with value has the greater dignity of objective status, which dignity confers on mankind the ought-to-be. ${ }^{59}$ In this way, Jonas unwaveringly asserts the inalienability of the value of man in the sense that it does not depend on what gain one may receive or how useful a man is for him to be of value. Thus, Jonas grounds his duty of responsibility for mankind on its inherent value.

\section{The Duty to Ensure the Future: The Theory of Responsibility Towards a Humanizing Ethics}

Jonas unequivocally maintains that "responsibility is first and foremost of men for men, and this is the archetype of all responsibility." ${ }^{60}$ This clearly highlights the reciprocity of responsibility: "I, who am responsible for someone, am always, by living among men, also someone's responsibility. ${ }^{, 61}$ In this light every living thing is its own end which needs no further justification and explicitly points out that man has nothing over other living beings except that he alone can have responsibility also for them thus guarding their self-purpose. ${ }^{62}$

Regarding its nature, Jonas notes that the first and most general condition of responsibility is that acting makes an impact in the world; the second that such action be under the agent's control; and the third, that he can foresee its consequences to some extent. Under these conditions, he holds that there can be responsibility in two senses: responsibility as being accountable for ${ }^{63}$ one's deeds and responsibility for ${ }^{64}$ particular objects, which responsibility commits an agent to particular deeds concerning them. ${ }^{65}$ But what compels us to a responsibility for the future?

Incumbent on usis the duty to ensure the future of man and his habitat, a duty which is non-reciprocal. Jonas insists:

The claim to existence begins only with existence. But the ethic we seek is concerned with just this not-yet-existent; and

\footnotetext{
${ }^{57}$ T. Alviraetalii, Metaphysics, 163.

${ }^{58} \mathrm{H}$. JONAS, The Imperative of Responsibility, 83.

${ }^{59}$ Ibid., 83-84.

${ }^{60}$ Ibid., 98.

${ }^{61}$ Ibid.

${ }^{62} \mathrm{H}$. JONAS, The Imperative of Responsibility, 98.

${ }^{63}$ Formal use of "for" in the sense that the doer is held responsible for the consequences of his deeds. This has primarily legal and not moral significance. (Ibid., 90).

${ }^{64}$ Substantive use of "for," meaning not an account for what has been done but the forward determination of what is to be done that is, feeling responsible for the matter that has claim on one's acting. (Ibid.,92).

${ }^{65}$ Ibid., 90.
}

its principle of responsibility must be independent of any idea of a right and therefore also of a reciprocity. ${ }^{66}$

Clearly, Jonas holds that it is mankind's duty to ensure the future existence of mankind. With this view, he considers the duty regarding posterity. The primary object of responsibility is humanity itself. What is more, this primary responsibility is to protect the future of humanity and then to safeguard the natural environment in a bid to safeguard posterity. ${ }^{67}$ In this wise we have "the duty to care for the now-existing child produced by us" and the future progeny, a duty "powerfully implanted in us by nature or at least in the childbearing part of humanity."68

Furthermore, Jonas admits that our duty charges us, in the first place, to ensure a future mankind and secondly, a duty toward their condition; in other words, the quality of their life. ${ }^{69}$ Although the above duty regarding posterity and that of future generations may sound an unwarranted repetition, Jonasgives a separate treatment of it and in my opinion, an emphasis on the mandatory nature of human existence. ${ }^{70}$

Ensuing from his standpoint of the imperative of the to-be of mankind and in a bid to guarantee the future existence of mankind, Jonas propounds a heuristics of fear. ${ }^{71}$ At the core of this principle, is the fact that human beings generally dread evil or calamities than perceive the good. This is highlighted when Jonas says: "We know the thing at stake when we know that it is at stake." 72 He further notes that "because this is the way we are made: the perception of the malum is infinitely easier to us than the perception of the bonum" ${ }^{\text {"73 }}$ and more so, "the magnitude of those stakes, taken together with the insufficiency of our predictive knowledge, leads to the pragmatic rule to give the prophecy of doom priority over the prophecy of bliss. $^{74}$

Cognizant of this human condition, Jonas maintains that our technological advances have to be guided by a future thinking of the worst scenarios as a consequence of our actions. In other words, we should always imagine the worst consequences of our action. ${ }^{75}$ Jonas thus sees this as a means of safeguarding mankind's first commandment and a means of ensuring the future existence of mankind ipso facto, contravening "the apocalypse threatening from the nature of the unintended dynamics of technical civilization." way Jonas formulates an ethics grounded on a naturalistic metaphysics rather than on divine revelation.

\footnotetext{
${ }^{66}$ Ibid., 39.

${ }^{67}$ L. VOGEL, "Introduction," in H. JONAS,The phenomenon of Life; Toward a Philosophical Biology, xvi.

${ }^{68}$ H. JonAs, The Imperative of Responsibility, 39-40.

${ }^{69}$ Ibid., 40.

${ }^{70}$ Ibid., 40-41.

${ }^{71}$ Ibid., 26.

${ }^{72}$ Ibid., 28.

${ }^{73}$ Ibid., 27.

${ }^{74}$ Ibid., $\mathrm{x}$.

${ }^{75} \mathrm{P}$. TAKOV, Deriving “Ought” from "Is" According to Hans Jonas, 102

${ }^{76} \mathrm{H}$. JONAS, The Imperative of Responsibility, 202
} 
Of interest to us at this juncture is the question: why did Jonas grant a non-preferential position to theology in advocating mankind's first commandment whence an ethics of responsibility for the future supervenes?

Jonas furnishes us, in this regard, with a fitting response when he notes that in an increasingly secular world, an ethics based upon a particular theology must seem parochial and dogmatic. Consequently, he seeks to derive an imperative of responsibility from nature; in fact, from the phenomenon of life. Such an imperative, he concludes, satisfies the need of reason to account for the dignity of human life and to ground our obligation for the surety of future generations. ${ }^{77} \mathrm{We}$ must also mention the fact that before grounding life's goodness in metaphysics, Jonas admits that, empirically speaking, the quantity of suffering in life outweighs the sum of enjoyment. ${ }^{78}$ Nonetheless, he declares that suffering rarely destroys the sentient self's will to live. Thus the metaphysical judgment of life's essential goodness cannot be made on hedonistic grounds. $^{79}$

Without any glimmer of uncertainty, we can say that Jonas views mankind as a "dignity-endowed entity" which stands today, more than ever before, threatened by man's very own unfettered technological ventures. Amidst this crisis, Jonas stands unencumbered in advocating that the existence of mankind is the first commandment.

\section{Stakes and Perspectives of Jonas's Consideration of Human Existence vis-à-vis Modern Technology}

Jonas, as we have seen, unequivocally holds that the human being is an absolute value and for no reason should it be put at stake neither by the individual nor by man's technological ventures as it stands threatened by medical research such as genetic engineering, human cloning, methods to extend human lifespan and even the threat of nuclear war.

Having considered Jonas's position regarding the ontological basis of the utmost necessity of human existence which stands threatened by modern technological advancement, we shall now re-examine some of his positions in view of proposing a way forward.

Jonas's profundity of thought finds expression, first of all, in his recourse to metaphysics. In an era prior to which the death of metaphysics had been sounded and its study considered redundant as was held by David Hume who stressed the vagueness of the concepts of metaphysics as well as pointing out that inferences about the world outside the mind cannot be proved with certainty, ${ }^{80}$ Ludwig Wittgenstein's view that philosophy as such has nothing positive to contribute, Jonas's bold and unremitting step in grounding his ethics for the technological age and the imperative of human existence based on the principles of metaphysics cannot be overlooked.

\footnotetext{
${ }^{77}$ L. VoGEL (ed.), "Introduction," in H. JONAs, Mortality and Morality, 3.

${ }^{78}$ Ibid., 13.

${ }^{79} \mathrm{Ibid}$.

${ }^{80}$ H. H. TITUS - M. S. SмIтH, Living Issues in Philosophy, 482.
}

Jonas himself was quite aware, in his own words, of the "ill repute" of metaphysics. That notwithstanding, he insisted that we cannot do without it and must dare turn to it again for it alone can furnish us with reasons why man ought to be, why he ought not bring about his disappearance in the world nor unwittingly allow this to happen. ${ }^{81}$ Unmistakably, then, we can say that the journey Jonas sought to undertake was a resolute one.Against the tides of the "scornful and contemptuous" outlook on metaphysics, ${ }^{82}$ Jonas stressed the imperative of human existence based on the ontological goodness of being. ${ }^{83}$

Verily, metaphysics is the foundational science for it studies being qua being. Acknowledging its inevitability in the realm of the practical sciences, ImreLakatos notes that scientific changes are connected with vast cataclysmic metaphysical revolutions. ${ }^{84}$ Furthermore, in the field of quantum physics, metaphysics has been in connection with quantum mechanics, in which subatomic particles arguably do not have the same sort of individuality as the particulars with which philosophy has traditionally been concerned. ${ }^{85}$

Again, metaphysics is at once the most basic and the most elevated of the sciences. It is the most basic in the sense that the concepts it handles are absolutely foundational and the most elevated in that those same concepts are given flight by metaphysicians and soar into the realms of abstraction. Hence, the value of metaphysics cannot be over emphasized in the sense that it deals with being as such, that which the intellect first conceives as well as the ultimate reality. Jonas's position regarding metaphysics is indicatively a call for the human mind to address itself to the whole of reality. In the words of Richard Wolin, one hereby senses that Jonas's entire philosophical being was directed against Wittgenstein's embarrassing proclamation concerning philosophy's irrelevance. ${ }^{86}$ From this perspective, we credit him for the giant step he initiated and the length he went to in asserting the irreprehensible nature of metaphysics.

Jonas fervently attests to the fact that the existence of mankind is an imperative based on the intrinsic dignity of human beings. ${ }^{87}$ His main thesis is that human beings have a

\footnotetext{
${ }^{81}$ H. JONAS, Mortality and Morality, 105.

${ }^{82}$ A description offered by I. Kant in the Preface to the first edition of the Critique of Pure Reason, re-echoing Christian Wolff that there was a time when metaphysics used to be called the queen of sciences but in our own century, it is quite fashionable to show contempt for it. (N. K. SMITH, Immanuel Kant's Critique of Pure Reason, Macmillan and Co Ltd., London 1929, 7-8). The above description perfectly squares the Scholastic conception and consideration of metaphysics as well as the primordial place they accorded metaphysics in philosophical reflection.

${ }^{83} \mathrm{H}$. JONAS, The Imperative of Responsibility, 98-100.

${ }^{84}$ L. IMRE, Science: Reason or Religion?,Bantam Books, New York 1975, 196.

${ }^{85}$ A. JONAS, Ontological Frameworks for Scientific Theories, Baker Books, New York 2012, 17.

${ }^{86}$ R. WOLIN, "Introduction. Ethics After Auschwitz: Hans Jonas's Notion of Responsibility in a Technological Age," in H. T. - SAMUELSON - C. WIESE (eds.), The Legacy of Hans Jonas: Judaism and the Phenomenon of Life, Brill, Boston 2008, 2.

${ }^{87} \mathrm{H}$. JONAS, The Imperative of Responsibility, 43.
} 
value and dignity which can neither be undermined nor encroached upon. From this fact, which stands as the basis of the "ought" of human existence, Jonas builds his novel ethic for the technological age. For him human beings have the priority of the duty to existence, ${ }^{88}$ and a human being is an end-in-himself Jonas stands as a voice in a crowd which considers man as an object which can be manipulated as far as human ingenuity permits as evinced by technology's recent ventures into fields which jeopardize the sacredness of human life namely, genetic engineering, human cloning, psychosurgery and behaviour control on highly experimental basis.

Clearly, then, man stands above all empirical objects. In tangent with Hans Jonas and in fact applauding his view regarding the dignity of man, Ian Barbour notes that "we have no right to tamper genetically with human nature or to accept policies that entail even the remote possibility of the extinction of humanity in a nuclear holocaust." ${ }^{" 89}$ In similar terms, Karol Wojtyla, who, like Jonas, witnessed the horrors of the Holocaust, posits that the human person should neither be used as an instrument nor as a means to an end..$^{90}$ It is for these same reasons that Jonas outrightly shuns suicide. ${ }^{91}$

Furthermore, it can be deduced from his writings that Jonas promotes the dignity of human life from the womb to the tomb. This is attested to when Jonas, according value to human life, makes reference to both actual and potential life. ${ }^{92}$ It is quite evident, then, that he decries any form of manipulation with human embryos, for example.

Worth bringing to the fore at this point is that the above stance by Jonas as qualifying life as "potential" and "actual" can lend itself to criticism by anti-abortionists (although Jonas does not overtly name it embryo). The whole philosophical scheme of Jonas is to bring to mind the fact that the human species is unique, dignity-endowed and beyond manipulation at all levels, from the womb to the tomb. This position of Jonas is clearly consistent with the teaching of the Congregation for the Doctrine of the Faith on thethe full anthropological and ethical status of human embryos according to which "the human embryo has, therefore, from the beginning, the dignity proper to a person." 93

We cannot also lose sight of Jonas's stance regarding death, an unexciting topic for many. Contrary to the misconstrued notion of death as an organic malfunction, thus, an enemy to be fought, Jonas considers death as "a necessity belonging to the nature of life," ${ }^{94}$ a point which Peter Kreeft articulates

\footnotetext{
${ }^{88}$ Ibid., 41.

${ }^{89}$ I. G. BARBOUR, Ethics in an Age of Technology, Harper San Francisco, New York 1993, 13.

${ }^{90}$ K. WoJTyla,Love and Responsibility, Ignatius Press, San Francisco 1993, 28.

${ }^{91} \mathrm{H}$. JONAS, Mortality and Morality, 105.

${ }^{92} \mathrm{H}$. JONAS, The Imperative of Responsibility, 101.

${ }_{93}$ CONGREgAtion FOR THE DOCTRINE OF THE FAITH,Instruction on Certain Bioethical QuestionsDignitas Personae, $\left(8^{\text {th }}\right.$ September 2008$)$, nn. 5.

${ }^{94}$ H. JONAS,The Imperative of Responsibility, 18.
}

when he says that "abolishing death by artificial immortality would make us all into rotten eggs." $"{ }^{5}$ In the same vein, the German existentialist, Martin Heidegger, affirms that death is a meaningful part of human life and indeed confers uniqueness and meaning to human existence for "as soon as man is born, he is old enough to die." ${ }^{96}$ Jonas therefore advocates for a positive outlook on death. We thus have every good reason to infer that Jonas recommends a preparation for death rather than despair as technology seeks to "remedy," a point which Joseph Omoregbe beautifully captures thus: "The awareness of an impending death therefore has some good effect on the way we live our life. It gives sense of urgency and makes us take time seriously." ${ }^{.97}$ In this vein, the words of St. Augustine would find particular significance when he affirms that "homo ex quo esse incipit in hoc corpore, in morteest" - "from the moment a man begins to exist in a body which is destined to die, he is involved all the time in a process whose end is death." ${ }^{.98}$

Worthy of our credit, once more, is the fact that Jonas proposes an imperative to safeguard the existence of mankind based on the necessity for present humanity to give up their short-term interest for the long-term benefits which we (the present generation) shall most assuredly not enjoy. ${ }^{99}$ It is an imperative which commands not love but a kind of intergenerational justice; a two-sided view which requires sacrificing not our lives but our short-term interests for the sake of long-term benefits that this present generation and even its children's children may not enjoy. Those coming after us will benefit from what we have left, but we will not benefit from the use that they may make of this. This brings an element of saintliness and sacrifice into Jonas's imperative of responsibility. It is the role of ethics to explain why such a future without the presence of present-day humanity has to be taken care of. ${ }^{100}$

The above text invigorates our assertion of altruism in Jonas's thought. Concretely, Jonas side-lines self-centred and egocentric tendencies as well as individualism which stifle growth and sacrifice. Today's humanity needs to think seriously about the existence of future humankind worthy of the name.

Undoubtedly, Jonas has made an indelible mark in upholding the dignity of mankind and the imperative of human existence. However, in advancing this all-good and relevant position, he makes certain claims which we find problematic and now seek to unveil for consideration.

\footnotetext{
${ }^{95} \mathrm{P}$. KREEFT,The Philosophy of Tolkien, 95.

${ }^{96}$ M. HeIDEGGER,Being and Time, Basil Blackwell, Oxford 1971, 289.

${ }^{97}$ J. I. OMOREGBE,A Simplified History of Western Philosophy, vol. 3, 58.

${ }^{98}$ Augustine, The City of God, XIII, 10 as quoted in B. Mondin,Philosophical Anthropology, M. A. CIZDYN (trans.), Theological Publications, Bangalore 1985, 262.

${ }^{99} \mathrm{H}$. JONAS, The Imperative of Responsibility, 39-40.

${ }^{100}$ L. VOGEL, "Jewish Philosophies after Heidegger: Imagining a Dialogue Between Jonas and Levinas," in Graduate Faculty Philosophy Journal, 1, (2001), 140 .
} 
In considering the primacy of human existence, Jonas contends that the existence of mankind (which is the first commandment) means that men should live on earth while the second commandment is that they live well. ${ }^{101}$ Furthermore, he maintains that once in existence, mankind, even if its initial cause is blind chance must be nurtured for it falls within the range of our responsibility. ${ }^{102}$

In our view, the initial cause of the existence of mankind by blind chance is certainly an inappropriate description which Jonas uses to propound the utmost care of human life incumbent on humanity. By and large, this is a contradiction for hitherto, he maintained the ontological goodness and value of human life "in all states" 103 and further specifying potential life in which case we refer to the unborn. ${ }^{104}$ Our worry then is: what does he mean by blind chance existence?

The implication of chance existence is a certain emanation from chaos, purposelessness, a lack of order and meaning, thus, the absence of an intelligent cause of events thus going contrary to David Rosever who, examining the order of the universe while simultaneously giving credit to creationism ${ }^{105}$ as opposed to evolutionism ${ }^{106}$ as theories which explain the origin of man, maintains that "all living things confirm the work of a Designer." 107

Furthermore, emanation from blind chance is a doctrine which finds its paradigmatic expression in Charles Darwin's The Origin of Species according to whom all life on earth, or at least its most interesting aspects, developed from a common ancestor over billions of years by utter chance, filtered through natural selection. ${ }^{108}$ Again, Lawrence Troster notes that chance existence is epitomized in modern nihilism. In this regard, he says:

In modern nihilism the natural world is no longer the divinely created order, but is a mindless purposeless process determined by inherent law. The natural world is also no longer "good" in the biblical sense but is instead indifferent to the distinction between good and bad. It has no purpose, no values, goals, or ends. In such a universe, humans are no longer created in the image of God. Darwinism has shown that the human species arose as the

\footnotetext{
${ }^{101} \mathrm{Cfr}$. H. JONAS, The Imperative of Responsibility, 100.

${ }^{102}$ Ibid., 101.

${ }^{103}$ Ibid.

${ }^{104}$ Ibid.

${ }^{105}$ Creationism is the doctrine which admits that God created the world and the living species in it. (D. AleXANDER, Creationism or Evolution: Do we have to Choose?, Monarch Books, Michigan 2009,295.)

${ }^{106}$ Evolutionism, with Charles Darwin (1809-1882) as its originator (who referred to it as descent with modification), states that all life on earth, or at least its most interesting aspects, developed from a common ancestor (or a few) over billions of years by utter chance, filtered through natural selection. (M. BEHE, The Edge of Evolution: The Search for the Limits of Darwinism, Free Press, New York 2007, 7.)

${ }_{107}$ D. ROSEVER,Creation Science: Confirming that the Bible is right, New Wine Press, Chichester 1991, 10.

${ }^{108} \mathrm{M}$. BEHE, The Edge of Evolution, 7.
}

result of random forces: "He is an accident, sanctified merely by success. ${ }^{109}$

The above quote stresses that existence from chance, expressed today in modern nihilism, implies purposelessness as opposed to the divinely created order. Commenting on blind chance existence, Roseveare definitively underscores the fact that such philosophy is unsatisfactory because it leaves no room for meaning and purpose in life and accordingly, death is the end of existence for the individual. ${ }^{110}$ Per contra, he, as regards the origin of each individual, ascribes to its origin from an intelligent and provident designer ${ }^{111}$ which Christianity calls God. In this light, the words of Pope Benedict XVI at the Mass of his installation as pope best express our stance: "We are not some casual and meaningless product of evolution; each of us is willed, each of us is loved, each of us is necessary."112

Jonas, in making strong claims regarding the imperative of human existence noted that the new imperative says precisely that we may risk our own life but not that of humanity. ${ }^{113} \mathrm{By}$ this, Jonas gives us the impression that there is more value accorded to an "agglomeration of lives" over a single life which sounds implausible and contradictory for the sum of the whole equals the sum of the parts just as "a part is a part of a whole."114 Said differently, it is a collection of individuals that makes up humanity as a whole. If understood as presented, the above position held by Jonas opens itself to ambiguity of interpretation and from our above established premises, it would be unsound to abide by.

In his theory of responsibility, Jonas clearly enunciates that human subjects are the primary objects of responsibility, ${ }^{115}$ implying that there exists secondary objects of responsibility. However, he further notes that every living thing is its end which needs no further justification and ipso facto, man has nothing over other living beings except that he alone can have responsibility also for them, that is, for guarding their selfpurpose. ${ }^{116}$ Stated clearly, our worry is: Does Jonas not give us an opening to believe that he places human beings on the same par as animals, especially when he says that human existence is the proper object of care because of its vulnerable

\footnotetext{
${ }^{109}$ L. Troster, "Caretaker or Citizen: Hans Jonas, Aldo Leopold, and the Development of Jewish Environmental Ethics," in H. T. - SAMUELSON - C. WIESE (eds.), The Legacy of Hans Jonas: Judaism and the Phenomenon of Life, 389.

${ }^{110} \mathrm{D}$. ROSEVER,Creation Science, 18.

${ }^{111}$ Ibid.

${ }^{112}$ http://www.vaticana.va/holy father/benedict xvi/homilies/2005/documents /hf ben-xvi hom 20050424 inizio-pontificato en.html. Accessed on 13/12/2014

${ }^{113} \mathrm{H}$. JONAS,The Imperative of Responsibility, 11.

${ }^{114}$ Plato, Parmenides, $137 \mathrm{c}$.

${ }^{115} \mathrm{H}$. JONAS,The Imperative of Responsibility, 98.

${ }^{116}$ Ibid.
} 
and revocable character ${ }^{117}$ - what his critics have called biotic egalitarianism? ${ }^{118}$

This position presents a contradiction because he, before now, has affirmed with unshakeable conviction that human existence is an imperative based on the ontological goodness of man which sets him above all other beings. This preponderant and unique position occupied by man had hitherto been stressed by Plato as well as Aristotle but based on the rational soul in man. ${ }^{119}$

Despite the above criticism, we cannot lose sight of the entire focus of Jonas's philosophy, namely, that human beings are dignity-endowed and that the environment cannot care for itself and so it is incumbent on us to include the environment among the objects of our responsibility lest it should rebel against us since its resources are not inexhaustible. This, as Lawrence Vogel notes, springs from the fact that the development of science and the uncritical outlook on human life have left us no longer believing that humanity belongs to the sacred order of essences in the totality of nature. In this regard, he further states, moderns have lost not only the grounds for cosmic piety but also a stable image of human nature. ${ }^{120}$ In clarifying the misunderstanding of biological egalitarianism ascribed to Jonas Vogel once more maintains:

Only humans, however, are able to discern the ontological truth: that the presence of being is "absolutely and infinitely" better than its absence. The consequence of this axiom is that we have an obligation to protect the life-world. But do all living things have equal ethical status? Jonas resoundingly answers, "No." The primary object of responsibility within the Good-in-itself of living nature, he contends, is humanity itself. $^{121}$

These perceptive words highlight the fact that Jonas presents the environment as an object of human responsibility with the view that the environment thus catered for would foster the existence of mankind. It is for this reason that Vogel once more asserts that Jonas's whole philosophy aims at explaining, in a manner consistent with modern science, why human destiny makes a real, objective difference - because living nature is essentially good, is worth being cared for so that we, her most sublime creation can continue to be. ${ }^{122}$ This gives us plausible reason why L. Troster endorses Jonas's critique of modern technology which has made nature into a mere object for the will of humanity and in this regard, joins Leon Kass in warning against genetic engineering in which

\footnotetext{
${ }^{117}$ Ibid.

${ }^{118}$ L. TROSTER, "Caretaker or Citizen: Hans Jonas, Aldo Leopold, and the Development of Jewish Environmental Ethics," in H. T. - SAMUELSON - C. WIESE (eds.), The Legacy of Hans Jonas: Judaism and the Phenomenon of Life, 392.

${ }^{119}$ H. H. Titus - M. S. SMith, Living Issues in Philosophy, 23.

${ }^{120}$ L. VoGEL, "Foreword," in H. JonAs, The Phenomenon of Life, xiii.

${ }^{121}$ Ibid., xvi.

${ }^{122}$ Ibid., xiv.
}

"the engineer engineers the engineer." 123 Once more, then, we note that the above assertion under consideration must be viewed within the ambient of Jonas's whole philosophical enterprise.

Prior to his consideration of mankind's existence imperative, Jonas asserted that traditional ethics has been anthropocentric in that it accorded moral worth only to persons ${ }^{124}$ ipso facto doing injustice to extra human nature ${ }^{125}$ and considered only short-range consequences of human actions. ${ }^{126}$ With this in mind, Jonas sought to rethink the foundations of traditional ethics in a bid to assert the imperative of man's existence as well as the need to care for nature so as to foster mankind's existence. In this way, he hoped to initiate a break in the anthropocentric ethic. But to what extent did he achieve this?

True to his goal, Jonas accorded value to nature and decried the extant ecological ravage as a result of technological advancement, notably, the threat of global warming as a result of the depletion of the ozone layer and indiscriminate felling of trees. In this regard, he viewed nature as something to be honoured. That notwithstanding, Jonas' novel ethic has been dubbed anthropocentric. ${ }^{127}$

L. Vogel adduces the fact that this possible accusation is not entirely unfounded because Jonas accords man a privileged place in evolution and insists that our primary obligation is to protect the existence and essence of human life. ${ }^{128}$ Vogel further observes that Jonas took into consideration the fact that living nature is a good-in-itself, commanding our reverence and while all organisms participating in this goodness are vulnerable ends-in-themselves who exhibit concern for their own being, humans have a yet special dignity as moral agents, ${ }^{129}$ hence, Jonas's primary ethical commandment - the duty to perpetuate the existence and essence of human life. ${ }^{130}$ On the whole, however, we must point out that Jonas's whole system is an intricate network which requires an acute eyesight in order to fathom the depth of its meaning lest the danger of misinterpretation and hasty generalisations. It is for this reason that Vogel, once more, observes that Jonas's metaphysics undercuts the very distinction between anthropocentricism and nonanthropocentricism. This, Vogel justifies by pointing out Jonas's emphasis that living nature is a good-in-itself, thus, commanding our reverence and, while all other organisms participating in this goodness are vulnerable ends-in-

\footnotetext{
${ }^{123}$ H. T. - SAMUELSON, "Preface; Understanding Jonas: An Interdisciplinary Project," in H. T. - SAMUELSON - C. WIESE (eds.), The Legacy of Hans Jonas: Judaism and the Phenomenon of Life, xxxix.

${ }^{124} \mathrm{H}$. JONAS, The Imperative of Responsibility, $\mathrm{x}$.

${ }^{125}$ L. VOGEL, "Editor's Introduction," in H. JONAS,Mortality and Morality, 17.

${ }^{126} \mathrm{H}$. JONAS, The Imperative of Responsibility, $\mathrm{x}$.

${ }^{127}$ L. VOGEL, "Editor's Introduction," in H. JONAS,Mortality and Morality, 17-18.

${ }^{128} \mathrm{Ibid} ., 17$

${ }^{129}$ Ibid.

${ }^{130}$ Ibid., 39.
} 
themselves who exhibit concern for their own being, humans have a special dignity as moral agents. ${ }^{131}$

Despite the above negative criticisms, Vogel maintains that "few would disagree with Jonas's general commandment" 132 the imperative of human existence. However, pre-empting any accusation of committing the fallacy of argumentum ad numerum, ${ }^{133}$ it is worth mentioning that Vogel took the above stance due to the plausibility and rigour of Jonas's thought regarding his main thesis - the ontological basis of the ought of human existence. ${ }^{134}$

From our study, we can deduce that when Jonas propounds the existence of mankind as the first commandment, it means, at the first level, that mankind must be; but at the second level, it also means that this being of mankind must be in accord with his inherent dignity and inalienable value. From this perspective, we see the intricate connection which Jonas establishes between human life and the material world which if indiscriminately trampled upon would inevitably endanger human life. Consequently, Jonas sees primordially human life and then the material world as commanding our ultimate respect, allegiance and final moral commitment.

\section{Technological Responsibility: Towards Building a Dignified Humanity}

Having considered the stance of our author this far, the abiding question is: How relevant are these thought-provoking and revealing realities to our contemporary society?

To begin with, we must highlight, as noted by Christian Wiese, the fact that although Jonas had a certain background from which he wrote, he neither secluded an audience nor directed his philosophical foray to a particular audience or group of readers for his philosophy had a universal appeal. ${ }^{135}$ Ideologies wrought by scientism, positivism, and the enlightenment have conjured a rather demeaning sociopolitical atmosphere along with its own sustaining philosophical ideologies which characteristically dethrone God and hand over to man the role of "lord and master" of himself and the universe - a situation fittingly described as Secularism. The traits and consequences are rife in today's society and include: anti-religion, collapse of morality, relativism, political upheaval, liberalism, the culture of the temporaryanonymity of modern life, acute materialism and the denial of transcendence.

\footnotetext{
${ }^{131}$ L. VOGEL, "Editor's Introduction," in H. JONAS,Mortality and Morality, 17 ${ }^{132}$ Ibid. 40 .

133 It consists of asserting that the more people support or believe a proposition, the more likely it is that that proposition is correct. (P. TAKOV N. Shang, Rudiments of Ordinary Level Logic, Destiny Prints, Bamenda 2014,153).

${ }^{134}$ L. VOGEL, "Editor's Introduction," in H. JONAS,Mortality and Morality, 39-40.

${ }^{135}$ H. T. - SAMUELSON, "Preface; Understanding Jonas: An Interdisciplinary Project," in H. T. - SAMUELSON - C. WIESE (eds.), The Legacy of Hans Jonas: Judaism and the Phenomenon of Life, xxv.
}

Individualism, it is worth mentioning, is one of the canker worms which, though obtrusively, eats up modern man and undermines "objectivism" - the basic conviction that there is or must be some permanent, ahistorical matrix or framework to which we can ultimately appeal in determining the nature of rationality, knowledge, truth, reality, goodness or rightness. ${ }^{136}$ Jonas's position is, for all ends and purposes, quite relevant in a time where Capitalism and Individualism are common currency in everyday economic life; a time where men have little or no concern for their fellowmen and treat one another with disregard and contempt; a time where many, even at all cost, strive to erect walls to protect and safeguard their comfort zones and protect their interests. These and a host of others constitute the dehumanizing tendencies in which contemporary society is enmeshed.

One of the major plagues of technology, resulting from its individualistic bent is today's belief that man is self-contented with what he has and does not need to go above himself to reach out to others and ultimately to the divine because technology conveniently satisfies his needs. Again, the rapid advancement in technology has bred the "culture of the temporary," the culture of the fleeting; nothing is stable, for no sooner is a product manufactured than it is abandoned for a better and more sophisticated innovation. From this point of view, man (and sometimes inadvertently) becomes a slave of technology, consumed in the culture of consumerism. However, Jonas rather sees life as a relationship characterized by transcendence and the need to foster relationships. ${ }^{137}$

Furthermore, the man of today needs the wisdom of philosophy even more urgently, given that the great advances in technology today require a renewed appreciation of ultimate values, without which technology would operate only on utilitarian principles and perhaps even finally lead to the destruction of the human race. Undeniably, we need a philosophy that is genuinely metaphysical in nature; a philosophy that can go beyond empirical data in order to reach something absolute, something ultimate and foundational. Wherever men discover a call to the absolute and transcendent, the metaphysical dimension of reality opens up before them in truth, in being, in moral values, in other persons, in being itself and ultimately in God. With the abolition of transcendence, man automatically accedes to technology and reveres it like a god.

Lamentably, most of the intractable difficulties which have arisen today, especially in the medical sciences (as evinced by the attempts at cloning a human being, controlling and altering human behaviour, genetic engineering, assisted conception and contraception), are a result of the inordinate deification of reason in scientific achievements together with the belief that through the application of technology, all the ills of man can be solved. Consequently, the machine takes

\footnotetext{
${ }^{136} \mathrm{R}$. J. BERNSTEIN,Beyond Objectivism and Relativism: Science, Hermeneutics and Praxis, University of Pennsylvania Press, Philadelphia $1983,7$.

${ }^{137}$ H. JONAS, Phenomenon of Life, 5.
} 
the place of Jesus Christ as the salvator mundi (saviour of the world), a mistaken view which sometimes takes the form of "technocratism" - the belief that if technically trained people could be put at the helm of decision making, all political problems would be solved. ${ }^{138}$ Above all, the main factor which has led to the exaggerated reverence for technology is a loss of the sense of the human identity.

One of the take-off points of Jonas is the point that "what we must avoid at all cost is determined by what we must preserve at all cost, and this in turn is predicated on the 'image of man' we entertain." "139 From this perspective, it is evident that Jonas considers the misconstrued image of man as the basis of our modern technological crisis. Corroborating this point, Abraham Heschel notes that one of the crises of modern man is that of a loss of identity which reflects itself in technological advancement. In this vein he asks: Do we live what we are or do we live what we have or by what we have? Reflecting on this, he comes to the realization that our difficulty is that we know so little about the humanity of man. ${ }^{140}$ Once more, he ponders: Is it not conceivable that the tragedy of modern man is due to the fact that he is a being who has forgotten the question, who is man? Admittedly, he sums up, "the failure of man is that of identifying himself, knowing what authentic human existence is and a consequent loss of sight of the very root of his being." ${ }^{141}$ The first step towards arriving at a humanizing conception of man is evidently dependent on restoring the lost exalted and sublime image of man as an incarnate spirit. We must therefore return to the call of Socrates, "Man, know thyself." It is from this perspective that the dictum: "thou canst because thou ought" would be restored. It is against this backdrop that we can confidently talk of the need for a re-orientation of technology.

The table below ${ }^{142}$ of some problems and their corresponding technological solutions and the long-term consequences vividly paints a picture of how acute Jonas's foresight was:

\begin{tabular}{|c|c|c|}
\hline Problem & $\begin{array}{l}\text { Technology as } \\
\text { Solution }\end{array}$ & Consequences \\
\hline $\begin{array}{c}\text { Food preservation, } \\
\text { temperature control: } \\
\text { nontoxic, non-flammable } \\
\text { refrigerant. }\end{array}$ & Chlorofluorocarbons & $\begin{array}{l}\text { Stratospheric Ozone } \\
\text { Depletion }\end{array}$ \\
\hline $\begin{array}{l}\text { Destruction of crops, } \\
\text { illness due to pests: agent } \\
\text { to kill insects. }\end{array}$ & $\begin{array}{l}\text { Synthetic } \\
\text { insecticides }\end{array}$ & $\begin{array}{c}\text { Adverse effects on } \\
\text { birds and mammals }\end{array}$ \\
\hline $\begin{array}{l}\text { Energy for consumer and } \\
\text { industry use: cheap and } \\
\text { readily available source. }\end{array}$ & Wood, coal & $\begin{array}{c}\text { Deforestation, } \\
\text { global climate } \\
\text { change }\end{array}$ \\
\hline $\begin{array}{l}\text { Increased food supply: } \\
\text { agent to aid crop growth }\end{array}$ & $\begin{array}{l}\text { Nitrogen and } \\
\text { phosphorus } \\
\text { fertilizers }\end{array}$ & Lake eutrophication \\
\hline
\end{tabular}

\footnotetext{
${ }^{138} \mathrm{H}$. Cox, "The Christian in a World of Technology," in I. BARBOUR (ed.),Science and Religion: New Perspectives on the Dialogue, SCM Press Ltd, London 1968, 267.

${ }_{139}$ H. JONAS,The Imperative of Responsibility, $\mathrm{x}$.

${ }^{140}$ A. J. HesCHEL, Who is Man?,Stanford University Press, California 1965, 6.

${ }^{141}$ A. J. HESCHEL, Who is Man?,Stanford University Press, California 1965, 6.

${ }^{142}$ T. GRAEDEL - B. R. ALLENBY,Industrial Ecology in http://www.en.wikipedia.org/wiki/hans_jonas. Accessed on 5/09/2014.
}

At crossroads as we are, we are faced with an intractable puzzle: does the solution to our predicament lie in an altogether abandonment of technology? Like our author, I. Barbour is of the opinion that technology should not be rejected in toto but be directed toward the realization of both human and environmental values. ${ }^{143}$ In this light, Jonas asserts that we should adopt policies designed to avert catastrophe rather than minimize short-range benefits. ${ }^{144}$ Again, quoting Albert Borgmann, Barbour insists that we should challenge technology and restrict it to the limited role of supporting the humanly meaningful activities associated with a simpler life ${ }^{145}$ and in Barbour's own terms, "the challenge for our generation is to redirect technology toward realizing human and environmental values on planet earth."146

Technology, as has been evident from the foregone discussion, is in dire need to be regulated by a moral rod if it is to be at the service of mankind for "science and technology are valuable resources for man when placed at his service and when they promote his integral development for the benefit of all." ${ }^{\prime 147}$ Yet, they cannot of themselves show the meaning of existence, hence, the need for human ingenuity via technology to be directed to the realization of human progress in a dignified way. If technology, as Teilliard de Chardin puts it, is to be man's participation in divine creativity, it must be at the service of the human person, of his inalienable rights and his true and integral goal. ${ }^{48}$ With Gabriel Marcel, we note that no one could deny that the existence of aeroplanes, phones, digital cameras, the internet, wireless sets seems to the vast majority of our contemporaries to be the proof or palpable gauge of progress. However, the price paid for such victories is high since the world in which we live is at one moment like a field for development and experimentation. ${ }^{149}$ The reality of various wars, ecological degradation as manifested in the recent alteration of the seasons and the threat of global warming are but a few proofs of the relevance of Jonas's position and the dire need for human ingenuity to be matched with morality.

\section{CONCLUSION}

Triggered by modern technological overtones, Jonas's unshakable conviction, which has been our focal point, is that the existence of mankind and the future existence of humanity rests on an ethics grounded on metaphysics, a stance which takes into account the intrinsic value of man as a being who is an "end-in-itself," hence, a good-in-himself. Commendably, he emphasizes the fact that technology is double-faced: it is able to lead to ethical good or evil. ${ }^{150}$ In fact, he noted that its

\footnotetext{
${ }^{143}$ I. BARBOUR, Ethics in an Age of Technology, 24.

${ }^{144} \mathrm{H}$. JONAS, The Imperative of Responsibility, $\mathrm{x}$.

${ }^{145}$ I. BARBOUR, Ethics in an Age of Technology, 15.

${ }^{146} I b i d .$, xix

${ }^{147}$ CONGREGATION FOR THE DOCTRINE OF THE FAITH,Instruction on Respect for Human Life in its Origin and on the Dignity of Procreation Donum Vitae (22 February 1987), nn. 2.

${ }^{148}$ I. BARBOUR, Ethics in an Age of Technology, 7

${ }^{149} \mathrm{G}$. MARCEL, The Mystery of Being, 187.

${ }^{15064} \mathrm{H}$. JONAS,Mortality and Morality, 103.
} 
good has the potential of turning into something bad due to its sheer growth and it is the enormity of this growth that will affect man's lot on earth and far into the future. ${ }^{151}$ In this regard, Jonas's grounding of the "good" or "value" in being is unavoidably a means to bridge the alleged chasm between the "is" and "ought." Clearly, the horrific events: the Hiroshima and Nagasaki bombings whose effects are still felt today and which would not have been possible if technology had not been what it is, continue to bear substantial testimony to Jonas's claims. Faced with these catastrophes, Jonas propounded the ethics of responsibility: responsibility for the environment and ultimately for human existence. In this light, we affirm with I. Barbour that the value of humankind requires a creative technology that is economically productive, ecologically sound, socially just and personally fulfilling. ${ }^{152}$ In a nutshell, technology without conscience can only lead to man's ruin. ${ }^{153}$ Consequently, the Jonasian standpoint is a clarion call of universal significance especially today given the rapidity of technological advancement with a disproportionate awareness of human dignity, hence, putting to jeopardy the existence of mankind.

\section{REFERENCES}

[1] AleXANDER Denis,Creationism or Evolution: Do we have to Choose?, Monarch Books, Michigan 2009.

[2] Alvira Tomas etalii,Metaphysics, SuPAn L. (trans.), Sinag-Tala Publishers, Manila 1991.

[3] Ashly M. Benedict, - O'Rourke D. Kevin, HealthCareEthics, The Catholic Hospital Association, Missouri 1978.

[4] AYER J. Alfred,Logical Positivism, The Free Pass Press, New York 1959.

[5] BANKIER David, "Holocaust," in Microsoft ${ }^{\circledR}$ Encarta $® 2009$ (DVD), Redmond, WA: Microsoft Corporation,2008.

[6] Barbour G. Ian,Ethics in an Age of Technology, Harper San Francisco, New York 1993.

[7] BARbour Ian (ed.),Science and Religion: New Perspectives on the Dialogue, SCM Press Ltd, London 1968.

[8] BEHE J. Michael, The Edge of Evolution: The Search for the Limits of Darwinism, Free Press, New York 2007.

[9] BERNSTEIN J. Richard, Beyond Objectivism and Relativism: Science, Hermeneutics and Praxis, University of Pennsylvania Press, Philadelphia 1983.

[10] Bierman K. Arthur - Gould A. James, Philosophy for a New Generation, Macmillan Publishing Co. Inc., New York 1981 ${ }^{4}$, $1977^{3}, 1973^{2}, 1970^{1}$

[11] ConANT James Bryant, Modern Science and Modern Man, Double Day, New York 1953.

[12] CONGREGATION FOR THE DOCTRINE OF THE FAITH, Instruction on Respect for Human Life in its Origin and on the Dignity of Procreation Donum Vitae (22 February 1987).

[13] _ Instruction on Certain Bioethical QuestionsDignitas Personae (08 September 2008).

[14] FISCHER Robert, Science, Man and Society, W. B. Saunders Company, Philadelphia 1971.

[15] GADAMER Hans - Georg, Hermeneutics, Religion and Ethics, WeINSHEIMER Joel (trans.), Yale University Press, London 1999.

[16] GADAMERHans-Georg, The Beginning of Knowledge,ColtMAn Rod (trans.), Continuum, London 2001.

${ }^{165} \mathrm{Ibid}$.

${ }^{166}$ I. BARBOUR, Ethics in an Age of Technology, 25.

${ }^{167}$ Cfr. CONGREGATION FOR THE DOCTRINE OF THE FAITH,Instruction on Respect for Human Life in its Origin and on the Dignity of Procreation Donum Vitae (22 February 1987), nn. 2.
[17] Heidegger Martin, Being and Time, Basil Blackwell, Oxford 1971.

[18] Heschel J. Abraham, Who is Man?,Stanford University Press, California 1965.

[19] Hudson W. Donald, Ludwig Wittgenstein. The Bearing of his Philosophy upon Religious Belief, John Knox Press, Virginia 1968.

[20] ImReLakatos, Science: Reason or Religion, Bantam Books, New York 1975.

[21] JONAS Arenhart,Ontological Frameworks for Scientific Theories, Baker Books, New York 2012.

[22] JONAS HansPhilosophical Essays: From Ancient Creed to Technological Man, University of Chicago Press, Chicago 1980.

[23] _ The Imperative of Responsibility. In Search of an Ethics for the Technological Age, H. Jonas - D. Herr (trans.), The University of Chicago Press, Chicago 1984.

[24] __ Mortality and Morality: A Search for the Good after Auschwitz, VoGel Lawrence (ed.), Northwestern University Press, Illinois 1996.

[25] - The Phenomenon of Life: Toward a Philosophical Biology, Harper and Row, New York 2001.

[26] Kant Immanuel, Critique of Pure Reason, Muller F. Max (trans.), Ancho Books Garden City, New York 1966.

[27] Kreeft J. Peter, The Philosophy of Tolkien. The Worldview behind the Lord of the Rings, Ignatius Press, San Francisco 2005.

[28] Manuel E. Frank (ed.), The Enlightenment, Prentice-Hall Inc., New Jersey 1955.

[29] MARCEL Gabriel, The Mystery of Being, University Press of America, New York 1984

[30] Mondin Battista,Philosophical Anthropology,Cizdyn A. Myroslaw (trans.), Theological Publications, Bangalore 1985.

[31] NGWA E. N. Collins, Technology and African Emancipation, Paper presented for discussion at the second Southern African Universities Social Sciences conference held at Dar-es-Salaam, (Unpublished), Tanzania 1979.

[32] Omoregbe I. Joseph,A Simplified History of Western Philosophy, vols. 2 \& 3, Joja Educational Research and Publishers Ltd., Lagos 1991.

[33] Plato, Parmenides, H. N. FowleR (trans.), Harvard University Press, London 1926.

[34] REICH T. Warrant (ed.), EncyclopaediaofBioethicsVols. 3 \& 4, The Free Press, New York 1978.

[35] ROSEVER David,Creation Science: Confirming that the Bible is right, New Wine Press, Chichester 1991.

[36] RUNES DavidDagobert(ed.), The Dictionary of Philosophy, Vision Press, London 1964.

[37] SAMUELSON-TiroshHava - WIESE Christian (eds.), The Legacy of Hans Jonas: Judaism and the Phenomenon of Life, Brill, Boston 2008.

[38] SARTRE Jean Paul, Being and Nothingness, Methuen, London 1969.

[39] SмITH Kemp Norman, Immanuel Kant's Critique of Pure Reason, Macmillan and Co Ltd., London 1929.

[40] TAKOv Peter, Deriving "Ought" from "Is" According to Hans Jonas, A Doctoral Thesis in the Faculty of Philosophy at the Pontifical Urban University, Rome (Unpublished), 2009.

[41] TAKOV Peter - SHANG Nelson, Rudiments of Ordinary Level Logic, Destiny Prints, Bamenda 2014.

[42] Titus S. Harold, - SMITH S. Marilyn, Living Issues in Philosophy, D. Van Nostrand Company, New York $1974^{6}, 1970^{5}, 1964^{4}, 1959^{3}$, $1953^{2}, 1946^{1}$.

[43] ThOMSON William, A Dictionary of Medical Ethics and Practise, John Wright \& Sons Ltd., Bristol 1977.

[44] VOGEL Lawrence, "Jewish Philosophies after Heidegger: Imagining a Dialogue Between Jonas and Levinas," in Graduate Faculty Philosophy Journal, 1, (2001), 119-146.

[45] Wojtyla Karol, Love and Responsibility, Ignatius Press, San Francisco 1993.

[46] http://www.en.wikipidia.org/wiki/hans_jonas.

[47] http://www.vaticana.va/holy_father/benedict_xvi/homilies/2005/do cuments/hf_ben-xvi_hom_20050424_inizio-pontificato_en.html. 